\title{
Minat Konsumen Terhadap Beras Organik di Daerah Istimewa Yogyakarta dan Jawa Tengah
}

\author{
D OI:10.18196/ agr.2234
}

\begin{abstract}
Various cases of food poisoning has caused people to more selective in choosing food by taking into account the health and food safety. Consumer awareness and preferences towards healthy food has resulted an increasing on consumption of organic food. This study aims to explain the consumer perceptions of organic rice, and its effect on consumer buying interest. The study was conducted by analized and interviewed 120 respondents. The binomial logit regression analysis was applied to explain the influence of consumer's perception on agricultural products. This research shows the consumers of organic rice come from various groups of people, most of them are from fixed-income consumer, high level of education, and small size family. Consumers of organic rice has a high concern on
\end{abstract}

their family, has a perception on high level of purity, and has high concern on the health of agricultural environment. However, consumers perception on organic farming practices was in moderate category. Organic agricultural products are still perceived as a high price product. Consumer interest on consuming organic rice would increase due to an increasing on consumer concerns on the family, perception of purity, concern on agriculture environmental health, and perception of the practice of organic farming.

Keywords: consumer concerns, consumer interest, consumer perception, organic rice

\section{INTISARI}

Berbagai kasus keracunan bahan makanan menyebabkan masyarakat semakin selektif dalam memilih bahan pangan dengan mempertimbangkan kesehatan dan keamanan pangan. Kesadaran dan preferensi konsumen terhadap pangan sehat mengakibatkan semakin meningkatnya konsumsi pangan organik. Penelitian ini dimaksudkan untuk mengungkap persepsi konsumen terhadap produk pertanian organik dan menjelaskan pengaruhnya terhadap minat beli konsumen. Data primer dikumpulkan dari 120 responden, selanjutnya dianalisis menggunakanregresi logit binomial. Hasil penelitian mengungkapkan konsumen beras organik berasal dari berbagai kelompok masyarakat, namun mayoritas berasal dari konsumen berpendapatan tetap, berpendidikan cukup tinggi, dengan ukuran keluarga yang kecil. Konsumen beras organik dicirikan dengan kepedulian terhadap keluarga, persepsi terhadap tingkat kemurnian dan kepedulian terhadap kesehatan lingkungan pertanian yang tinggi. Namun, konsumen masih mempunyai persepsi yang termasuk dalam katagori sedang terhadap praktek pertanian organik; hasil pertanian organik masih dipersepsikan sebagai produk yang mempunyai harga mahal. Meningkatnya kepedulian terhadap keluarga, persepsi terhadap tingkat kemurnian, kepedulian terhadap kesehatan lingkungan pertanian, dan persepsi terhadap praktek pertanian organik akan meningkatkan minat beli konsumen terhadap beras organic. 
Kata kunci: beras organik, minat konsumen, kepedulian konsumen, persepsi konsumen

\section{PENDAHULUAN}

Indonesia mempunyai potensi yang besar untuk mengembangkan produksi dan pemasaran produk pertanian organik, termasuk beras. Areal lahan pertanian organik di Indonesia meningkat dari 17.783 ha pada tahun 2005 menjadi 66.184 ha pada tahun 2007 (www.organic-world.net), namun belum semuanya dapat menghasilkan produk organik tersertifikasi organik. Pertanian padi organik telah dikembangkan di beberapa sentra produksi padi, antara lain di Jawa Barat, Jawa Tengah, Jawa Timur dan Bali. Beras organik sekarang dapat dijumpai di banyak toko eceran (IFOAM 2009) dengan beragam label yang menunjukkan sebagai produk pertanian organik.

Keputusan konsumen untuk membeli dan mengkonsumsi suatu barang dipengaruhi oleh berbagai faktor, seperti strategi pemasaran, lingkungan tempat tinggal konsumen, dan perbedaan individu. Menurut Engel et. al. (1993) faktor yang secara bersama-sama mempengaruhi keputusan konsumen dalam membeli, memilih dan mengkonsumsi produk barang dan jasa antara lain faktor lingkungan, faktor individu dan faktor psikologis yang terjadi pada diri seseorang. Konsep pengambilan keputusan konsumen yang dikemukakan Engel tersebut didukung berbagai studi empiris berikut. Ricciuto et. al. (2006) yang menyatakan bahwa ukuran keluarga, komposisi, pendapatan, dan pendapatan secara bersama-sama memberikan penjelasan sebesar 21-29\% variasi pembelian dan konsumsi pangan di Kanada.

Berbagai kasus keracunan bahan makanan dan kasus keamanan pangan (misalnya wabah sapi gila di Eropa dan pemberian formalin sebagai bahan pengawet makanan di Indonesia) menyebabkan masyarakat semakin selektif dalam memilih bahan pangan, yaitu dengan mempertimbangkan kesehatan dan keamanan pangan (Fotopoulos dan Krystallis, 2002). Kesadaran dan preferensi konsumen terhadap pangan sehat mengakibatkan semakin meningkatnya konsumsi pangan organik (Connor dan Douglas, 2002).

Produk organik, termasuk beras organik merupakan pangan yang dihasilkan oleh pertanian organik (Biao, 2003). Pangan organik diyakini lebih aman (Canavari et. al. 2002) karena merupakan pangan alami yang dihasilkan tanpa menggunakan bahan kimia dan pupuk buatan (Connor dan Douglas, 2002). Produk pangan organik dihasilkan dari pertanian organik, yaitu suatu sistem produksi yang mempertahankan kesehatan tanah, ekosistem dan manusia.

Dalam benak konsumen, produk organik lebih baik dan lebih sehat dibandingkan produk pertanian konvensional. Citra produk yang lebih baik ini menjadi motif utama bagi konsumen yang bersedia membeli dengan harga lebih tinggi untuk membeli pangan organik. Dari titik pandang ilmiah, adalah sulit untuk membenarkan kemanfaatan kesehatan dari produk organik. Penelitian Schumpbach menemukan bahwa terdapat perbedaan fakta antara produk organik dan konvensional terkait dengan pertimbangan residu pestisida. Jika pangan diproduksi secara murni dengan menggunakan metode organik diuji, hasil adalah lebih bersih dari residu pestisida (Schumpbach dalam Baio, 2003).

Keunggulan produk pertanian organik masih menjadi perdebatan, namun diyakini bahwa proses produksi pertanian organik lebih ramah lingkungan. Perilaku konsumen terkait dengan kualitas beras organik dan kepedulian konsumen pada lingkungan penting untuk mendapat penjelasan secara mendalam. Penelitian ini bertujuan untuk mengenali minat beli konsumen terhadap beras organik. Penelitian ini merupakan bagian dari penelitian jangka panjang yang bertujuan untuk meningkatkan konsumsi masyarakat terhadap pangan sehat yang ramah lingkungan dan dihasilkan secara domestik.

\section{METODE PENELITIAN}

Penelitian dirancang sebagai penelitian deskriptif, yaitu penelitian yang bertujuan untuk mendeskripsikan karakteristik konsumen (Malhotra, 2004). Dalam penelitian ini karakteristik pasar yang akan dideskripsikan mencakup perilaku pembelian beras organik, perilaku konsumen terkait dengan kualitas beras organik dan persepsi konsumen terhadap pertanian organik. Penelitian dirancang dengan metode survei untuk mencapai tujuan yang diformulasikan sebelumnya (Malhotra, 2004).

Penelitian dilakukan terhadap beras organik yang dihasilkan di Kabupaten Sragen, salah satu daerah sentra produksi beras organik di Jawa Tengah. Pengambilan data dilakukan dengan pengambilan sampel secara nyaman. Secara keseluruhan, 120 orang pembeli yang sedang 
melakukan pembelian beras organik di pengecer beras organik di Surakarta, Semarang dan Yogyakarta dijadikan sampel.

Minat didekati dengan preferensi konsumen terhadap beras organik yang merupakan variabel binomial. Untuk menganalisis faktor yang berpengaruh terhadap minat beli konsumen dilakukan analisis logit binomial, dengan model model sebagai berikut.

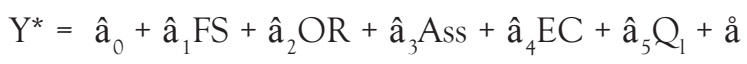

di mana

$$
\mathrm{Y}^{x}=\operatorname{Ln}\left(\frac{\mathrm{P}}{1-\mathrm{P}}\right)
$$

P : preferensi beli konsumen terhadap beras organik

$=1$ jika konsumen lebih suka beras organik

$=0$ jika konsumen tidak lebih suka beras organik

FS : Kesadaran pada makanan keluarga (rata-rata skor)

OR: Persepsi pada produk organik (rata-rata skor)

Ass: Persepsi mutu beras organik (rata-rata skor)

EC: Kepedulian terhadap kesehatan lingkungan hidup (rata-rata skor)

Penyelesaian regresi model logit ordinal dilakukan dengan metode Maximum Likelihood Estimation (MLE) dengan bantuan program komputer Eviews. Dalam penyelesaian regresi ini digunakan: i) nilai McFadden's R2 untuk mengetahui ketepatan model yang dinyatakan sebagai persentase variasi variabel preferensi konsumen yang dapat dijelaskan oleh variabel bebas; ii) nilai Likelihood Ratio digunakan untuk menguji pengaruh variabel bebas secara bersama-sama; iii) nilai wald (statistik-z) untuk menguji pengaruh variabel bebas (independent variable) secara individual terhadap variabel tidak bebas (dependent variable). Hasil analisis model regresi logit ordinal diinterpretasikan sebagai dampak perubahan variabel dependen terhadap probabilitas preferensi seseorang, dengan mempertahankan variabel lain konstan.

\section{HASIL DAN PEMBAHASAN}

\section{KONSUMEN BERAS ORGANIK}

Perilaku konsumen berarti tindakan yang langsung terlibat dalam mendapatkan, mengkonsumsi, dan menghabiskan produk dan jasa, termasuk proses keputusan yang mendahului dan menyusuli tindakan ini.
Hal ini lebih menekankan bahwa perilaku konsumen (consumer behavior) sebagai studi tentang unit pembelian (buying units). Profil responden sebagaimana ditampilkan pada Tabel 1 menunjukkan bahwa konsumen beras organik adalah kelompok keluarga dengan usia yang beragam, berpenghasilan yang tetap, dengan tingat pendidikan yang relatif tinggi.

Usia kepala keluarga konsumen beras organik relatif tersebar dalam kelompok usia muda, usia matang, usia tua dan usia lanjut. Namun, kepala keluarga konsumen beras organik dari kelompok usia 36-50 tahun lebih dominan dibandingkan kelompok usia lainnya. Pada umumnya keluarga dari kelompok usia ini mempunyai kondisi ekonomi yang telah mapan, sehingga kebutuhan terhadap konsumsi makanan yang memberikan dampak kesehatan yang baik bagi anggota keluarga sudah mulai mendapat perhatian.Seperti halnya usia kepala keluarga, usia ibu rumah tangga keluarga responden konsumen beras organik juga didominasi oleh kelompok usia 36 50 tahun.

Tingkat pendidikan kepala keluarga dan juga ibu rumah tangga responden konsumen beras organik, didominasi dengan kelompok pendidikan serendahrendahnya setingkat SLTA. Konsumen dengan tingkat pendidikan dasar dan lanjutan pertama merupakan kelompok yang sangat kecil, yaitu kurang 5\%. Tingkat pendidikan seseorang mempengaruhi cara berpikir, cara pandang, bahkan persepsi terhadap suatu permasalahan. Kepala keluarga dan ibu rumah tangga konsumen beras organik merupakan kelompok masyarakat yang relatif mampu berpikir lebih rasional jika dilihat tingkat pendidikannya.

Pekerjaan kepala keluarga responden konsumen beras organik secara umum didominasi oleh kelompok pegawai negeri/TNI/Polri dan karyawan tidak tetap/buruh. Ibu rumah tangga keluarga konsumen beras organik pada umumnya mempunyai pekerjaan. Di antara ibu rumah tangga yang bekerja, kebanyakan ibu rumah tangga bekerja sebagai pegawai negeri dan karyawan tidak tetap.

\section{KUALITAS BERAS ORGANIK MENURUT PENILAIAN KONSUMEN}

Kualitas beras bersifat multidimensi, yang mencakup karakteristik fisik yang berpengaruh pada penampilan dan karakteristik kemis yang berpengaruh pada kualitas tanakan. Karakteristik fisik meliputi ukuran butiran, derajat putih, butir kepala, kejernihan butir, aroma, benda asing, dan butir pecah. Kualitas kemis meliputi 
kandungan amilosa, suhu gelatinisasi, dan konsistensi jel.

Kualitas beras ditentukan oleh varietas, keadaan proses produksi dan panen, penanganan pasca panen, penggilingan dan pemasaran. Varietas secara langsung menentukan beberapa karakteristik kualitas dan berinteraksi dengan keadaan lingkungan dan pengolahan berpengaruh secara tidak langsung terhadap karakteristik lainnya.

Secara umum penanganan proses produksi padi organik sampai dengan pasca panen di Sragen berbeda dengan pertanian konvensional, terutama pada kelompok tani yang telah bersertifikasi. Perbedaan yang sangat nyata terletak pada fungsi kelompok tani yang sangat besar, mulai dari pengelolaan pergiliran penanaman, pemantauan proses produksi, pengelolaan dan penanganan panen, dan pemasaran beras organik.

Pengelolaan pergiliran tanaman dilakukan oleh kelompok tani untuk menjaga keberlanjutan ketersedian gabah organik dan menghindari terjadinya penumpukkan produksi pada waktu tertentu. Walaupun tidak dengan jadwal yang terperinci, namun kelompok tani mengatur saat penanaman padi organik untuk suatu blok sawah tertentu, sehingga ketersediaan padi organik lebih terjaga dan tidak terjadi penumpukkan produksi. Pemantauan proses produksi dilakukan untuk menjamin bahwa semua anggota kelompok tani melakukan standar pertanian organik yang telah ditetap oleh kelompok dan memantau perkembangan hama dan penyakit.

Hasil penelitian menunjukkan bahwa konsumen mempunyai persepsi yang lebih baik terhadap banyaknya butir utuh dibandingkan dengan warna butiran beras (Tabel 2). Banyaknya butir utuh merupakan karakteristik utama yang digunakan oleh pedagang dan konsumen untuk menilai kualitas beras pada umumnya.

TABEL 2. EVALUASI KONSUMEN TERHADAP PENAMPILAN BERAS ORGANIK

\begin{tabular}{lll}
\hline No. & Penampilan beras & Skor \\
\hline 1 & Banyaknya butir kepala & 2,86 \\
2 & Warna butiran & 2,41 \\
3 & Banyaknya butir kapur & 3,35 \\
4 & Banyaknya butir coklat & 3,48 \\
5 & Banyaknya benda asing & 3,57 \\
& Rata-rata & 3,13 \\
\hline
\end{tabular}

Beras organik yang dipasarkan mempunyai kualitas yang beragam ditinjau dari banyaknya butir utuh. Sebagian besar konsumen menilai beras organik yang dipasarkan mempunyai jumlah butir utuh dalam kategori
TABEL I. PROFIL KEPALA KELUARGA DAN IBU RUMAH TANGGA KONSUMEN

\begin{tabular}{|c|c|c|c|}
\hline No & Uraian & Jumlah (Jiwa) & Persentase (\%) \\
\hline \multirow[t]{5}{*}{1} & Usia Kepala keluarga & & \\
\hline & 20 - 35 tahun & 32 & 27 \\
\hline & $36-50$ tahun & 57 & 47 \\
\hline & $51-64$ tahun & 24 & 20 \\
\hline & 65 tahun atau lebih & 7 & 6 \\
\hline \multirow[t]{5}{*}{2} & Usia ibu rumah tangga & & \\
\hline & 20 - 35 tahun & 30 & 25 \\
\hline & $36-50$ tahun & 58 & 48 \\
\hline & $51-64$ tahun & 27 & 23 \\
\hline & 65 tahun atau lebih & 5 & 4 \\
\hline \multirow[t]{5}{*}{3} & Pendidikan kepala keluarga & & \\
\hline & SD & 1 & 1 \\
\hline & SMP & 5 & 4 \\
\hline & SMA & 44 & 37 \\
\hline & Perguruan tinggi & 70 & 58 \\
\hline \multirow[t]{5}{*}{4} & Pendidikan ibu rumah tangga & & \\
\hline & SD & 3 & 2,5 \\
\hline & SMP & 3 & 2,5 \\
\hline & SMA & 58 & 48 \\
\hline & Perguruan tinggi & 56 & 47 \\
\hline \multirow[t]{6}{*}{5} & Pekerjaan kepala keluarga & & \\
\hline & PNS/TNI/Polri/Pensiunan & 38 & 31 \\
\hline & Karyawan swasta & 7 & 6 \\
\hline & Karyawan tidak tetap/ buruh & 50 & 42 \\
\hline & Wiraswasta & 20 & 17 \\
\hline & Lainnya & 5 & 4 \\
\hline \multirow[t]{7}{*}{6} & Pekerjaan ibu rumah tangga & & \\
\hline & PNS/TNI/Polri/Pensiunan & 25 & 21 \\
\hline & Karyawan swasta & 8 & 7 \\
\hline & Karyawan tidak tetap/ buruh & 32 & 27 \\
\hline & Wiraswasta & 4 & 3 \\
\hline & Lainnya & 3 & 2 \\
\hline & Tidak bekerja & 48 & 40 \\
\hline
\end{tabular}

sedang sampai dengan banyak. Sebagian beras organik yang dipasarkan telah dilakukan penyortiran butir pecah, namun juga dijumpai beras organik yang masih bercampur antara butir pecah dengan butir utuh. Pelaku pemasaran melakukan pemilahan butir utuh dari butir pecah bersamaan dengan penggilingan padi. Penyortiran 
ini dilakukan oleh pemasok berdasarkan kesepakatan dengan pedagang pengecer beras organik. Pedagang pengecer akan melakukan negosiasi ulang terhadap harga apabila ternyata beras yang dikirim oleh pemasok tidak sesuai dengan yang diharapkan. Pemasok beras organik yang tidak mempunyai gabah yang baik, sehingga didapatkan butir pecah dengan jumlah yang tinggi, akan menjual beras tersebut tanpa dilakukan pemilahan terlebih dahulu.

Pedagang pengecer pada umumnya tidak mensyaratkan warna butiran beras organik pada saat melakukan pemesanan dan pembelian beras organik. Sebagian besar konsumen menilai beras organik yang dipasarkan mempunyai warna butiran yang cukup putih dan kurang putih. Keberagaman warna butiran beras tersebut disebabkan karena faktor cuaca yang menyebabkan petani mengalami kesulitan untuk segera menjemur gabah. Pada umumnya konsumen masih mentolerir keadaan warna butiran beras organik. Pemasok beras organik mengolah gabah organik untuk mendapatkan beras dengan warna butir yang terbaik yang mampu dihasilkan dari gabah yang tersedia dengan pertimbangan banyaknya butir utuh.

Hasil penelitian menunjukkan bahwa konsumen menilai butir kapur dan butir coklat pada beras organik yang dipasarkan dalam jumlah yang sangat sedikit dan sedikit. Butir kapur dan butir coklat diperoleh dari gabah yang tidak masak sempurna dan atau cacat akibat terserang hama. Proses produksi padi organik yang dilakukan dengan pengawasan dan pemantauan secara intensif baik oleh kelompok tani maupun oleh penyuluh. Kualitas beras yang rendah akibat tercampur butir kapur atau butir coklat sudah dapat diantisipasi saat pemantauan proses produksi. Apabila ternyata gabah yang dihasilkan tidak masak keseluruhan atau ditemukan banyak butir hampa, maka petani diminta untuk menyortir gabah tersebut sampai memenuhi syarat kelompok tani. Dengan demikian akan didapatkan beras organik dengan butir kapur dan butir hampa yang sangat sedikit.

Benda asing merupakan benda bukan beras yang terikut dalam beras. Konsumen menilai benda asing yang terikut dalam beras organik yang dipasarkan dalam jumlah sedikit dan sangat sedikit. Benda asing biasanya adalah batu kecil yang terikut dalam gabah ketika dipanen, dijemur atau digiling sampai pengemasan. Penjemuran gabah dilakukan pada lantai jemur, baik oleh kelompok tani maupun perusahaan pengolah beras organik. Penjemuran yang dilakukan demikian ini rawan terjadi kontaminasi benda asing. Jika pengolah melakukan sortasi butir pecah, maka butir kapur, butir coklat dan benda asing akan tersortasi bersamaan dengan butir pecah tersebut, sehingga didapatkan beras organik dengan jumlah benda asing yang sangat sedikit.

Karakteristik hasil tanakan nasi dipengaruhi oleh sifat kimia beras. Sifat kimia ini ditentukan oleh varitas padi dan kondisi lingkungan produksi. Kandungan amilosa pada beras menentukan volume keterkembangan, konsistensi jel menentukan kekerasan nasi (Unnevehr etal, 1992). Beras organik yang banyak dipasarkan adalah menthik wangi, menthik susu, pandan wangi dan IR64.

Varitas menthik wangi merupakan varitas lokal yang dicirikan dengan aroma wangi yang khas, nasi pulen. Beras menthik susu mempunyai warna putih seperti beras ketan, beraroma wangi sebagaimana menthik wangi, nasi pulen. Pandan wangi merupakan varitas lokal yang beraroma pandan, nasi pulen, sedangkan IR 64 merupakan varitas baru yang tidak beraroma wangi.

Konsumen menilai beras organik yang dipasarkan mempunyai karakteristik tekstur dan katahanan simpan yang lebih baik dibandingkan dengan karakteristik aroma, volume keterkembangan dan rasa manis (Tabel 3). Beras organik merupakan beras yang dihasilkan dari proses produksi pertanian dengan pengawasan yang lebih baik dibandingkan dengan nonorganik. Pengawasan proses produksi yang lebih baik tersebut akan menghasilkan butiran beras yang lebih baik, sehingga nasi yang dihasilkan dari beras organik mempunyai karakteristik ketahanan simpan yang baik. Varitas padi organik pada umumnya merupakan varitas menengah sampai dengan varitas super, misalnya menthik, menthik wangi, atau menthik susu. Dengan demikian nasi yang dihasilkan dari beras organik mempunyai tekstur yang pulen.

\section{TABEL 3. EVALUASI KONSUMEN TERHADAP KARAKATERISTIK HASIL} TANAKAN NASI BERAS ORGANIK

\begin{tabular}{lll}
\hline No. & Karakteristik tanakan & Skor \\
\hline 1 & Kepulenan/tekstur nasi & 2,72 \\
2 & Aroma nasi & 2,50 \\
3 & Volume keterkembangan nasi & 2,44 \\
4 & Rasa manis nasi & 2,64 \\
5 & Ketahanan simpan nasi & 2,84 \\
& Rata-rata & 2,63 \\
\hline
\end{tabular}




\section{PERSEPSI KONSUMEN TERHADAP BERAS ORGANIK}

Salah satu fungsi keluarga adalah fungsi ekonomi yaitu fungsi untuk menyediakan kebutuhan fisik yang cukup dan memadai bagi semua anggota keluarga. Keluarga berkewajiban untuk menyediakan makanan, minuman, pakaian, rumah, pemeliharaan kesehatan, pendidikan. Dalam penelitian ini kepedulian konsumen didekati dengan 3 pernyataan yang diukur dengan skala Likert. Hasil penelitian menunjukkan bahwa semua responden konsumen beras organik mempunyai kepedulian yang tinggi terhadap pentingnya makanan untuk memelihara kesehatan anggota keluarganya (Tabel 4).

\section{TABEL 4. PERSEPSI KONSUMEN TERHADAP PERANAN MAKANAN BAGI KESEHATAN KELUARGA}

\begin{tabular}{llr}
\hline No. & Pernyataan & Skor \\
\hline 1 & Makanan berpengaruh terhadap kesehatan keluarga & 4,83 \\
2 & Makanan bergizi penting bagi keluarga & 4,74 \\
3 & Makanan yang terbebas dari zat berbahaya penting bagi keluarga & 4,20 \\
& Rata-rata & 4,59 \\
\hline
\end{tabular}

Menurut SNI 6729-2010, pertanian organik dilakukan dengan mengelola ekosistem untuk mencapai kesuburan berkelanjutan. Kesuburan tanah dijaga dan ditingkatkan dengan mengoptimalkan aktivitas biologi tanah, sedangkan manajemen hama dan penyakit dilakukan dengan merangsang hubungan seimbang antara inang/ predator, pengendalian biologi, dan peningkatan populasi serangga yang menguntungkan. Dalam prakteknya pertanian organik dipahami sebagai pertanian yang tidak menggunakan pupuk dan pestisida sintesis.

Pertanian organik diyakini sebagai proses yang bersih sehingga menghasilkan produk yang bersih dari residu. Hasil penelitian ini menunjukkan bahwa beras organik dipersepsikan oleh konsumen sebagai produk yang terbebas dari zat berbahaya, menghasilkan produk yang berasa lebih enak dan lebih bergizi, walaupun penampilan secara fisik produknya kurang baik, bahkan konsumen merasa sulit untuk mendapatkan di pasaran dengan harga yang mahal pula (Tabel 5). Hasil penelitian ini sesuai dengan pernyataan Sangkumchaliang dan Huang (2012) bahwa produk organik dipersepsikan oleh sebagian besar konsumen sebagai produk yang ramah lingkungan, produk yang sehat, tidak membawa residu pestisida, pertanian organik tidak menggunakan pestisida sintesis.

\section{TABEL 5. PERSEPSI KONSUMEN TERHADAP PERTANIAN ORGANIK}

\begin{tabular}{lll}
\hline No. & Pernyataan persepsi konsumen & Skor \\
\hline 1 & Produk pertanian organik terbebas dari zat berbahaya & 4,38 \\
2 & Produk pertanian organik terasa lebih enak & 4,26 \\
3 & Produk pertanian organik lebih bergizi & 4,29 \\
4 & Produk pertanian organik lebih mahal & 2,20 \\
5 & Produk pertanian organik lebih sulit diperoleh & 2,60 \\
6 & Penampilan fisik produk pertanian organik lebih baik & 3,62 \\
& Rata-rata & 3,56 \\
\hline
\end{tabular}

Produk pertanian organik tidak mudah dibedakan dengan produk pertanian konvensional, karena yang membedakan antara keduanya adalah proses produksi pertanian yang dilakukan oleh petani dan juga proses pengolahan pasca panennya. Selama proses produksi pertanian organik sangat rentan terhadap penyimpangan standar yang dapat dilakukan oleh petani, pengolah hasil, dan juga oleh pedagang beras organik. Berbagai penyimpangan yang mungkin dilakukan tersebut hampir tidak mungkin dapat diketahui oleh konsumen jika hanya mendasarkan pada produknya semata. Oleh karenanya tingkat kemurnian produk organik didasarkan pada perkiraan konsumen terhadap proses produksi dan pengolahan pasca panen.

Hasil penelitian menunjukkan bahwa konsumen beras organik petani, pedagang beras organik telah melakukan proses yang sesuai dengan standar praktek pertanian organik sehingga beras yang dihasilkan juga dipersepsikan telah memenuhi standar organik (Tabel 6).

\section{TABEL 6. PERSEPSI KONSUMEN TERHADAP TINGKAT KEMURNIAN BERAS ORGANIK}

\begin{tabular}{|c|c|c|}
\hline No. & Pernyataan persepsi konsumen & Skor \\
\hline 1 & $\begin{array}{l}\text { Petani padi telah melakukan proses produksi sesuai standar } \\
\text { organik }\end{array}$ & 3,61 \\
\hline 2 & Beras organik telah memenuhi standar produk organik & 4,01 \\
\hline 3 & $\begin{array}{l}\text { Pedagang tidak melakukan pencampuran beras organik dengan } \\
\text { nonorganik }\end{array}$ & 3,47 \\
\hline & Rata rata & 3,70 \\
\hline
\end{tabular}

Beberapa penelitian menunjukkan karakteristik etis produk pertanian organik merupakan faktor yang mendorong pembelian produk pertanian organik. Gianluigi et al (2009) menyatakan pertimbangan etis adalah akibat yang lebih baik dari konsumsi produk 
organik, sedangkan Zander dan Hamm (2010) menggunakan pendekatan karakteristik etik sebagai keselamatan hewan, diproduksi secara regional, harga yang adil untuk petani, diproduksi pada usahatani yang berhati-hati, dan melindungi biodiversitas. Dalam penelitian ini kepedulian konsumen terhadap kesehatan lingkungan, didekati dengan 4 pernyataan yang berkaitan dengan akibat yang baik dari praktek pertanian organik.

Hasil penelitian menunjukkan bahwa konsumen beras organik mempunyai kepedulian yang tinggi terhadap kesehatan lingkungan pertanian (Tabel 7). Dengan membeli beras organik, konsumen berharap petani dapat mengurangi penggunaan pupuk an-organik dan pestisida kimia sintesis, meningkatkan penggunaan pupuk organik dan pestisida alami. Konsumen berharap dapat membantu meningkatkan kualitas lingkungan lahan pertanian dan mengurangi resiko keracunan akibat penggunaan pupuk dan pestisida kimia sintesis.

\section{TABEL 7. KEPEDULIAN KONSUMEN TERHADAP KESEHATAN LINGKUNGAN PERTANIAN}

\begin{tabular}{lll}
\hline No. & Pernyataan persepsi konsumen & Skor \\
\hline 1 & $\begin{array}{l}\text { Hendaknya membantu petani mengurangi penggunaan pupuk } \\
\text { kimia }\end{array}$ & 4,13 \\
2 & $\begin{array}{l}\text { Hendaknya membantu petani memperbanyak pemakaian } \\
\text { pupuk organik untuk meningkatkan kesuburan tanah }\end{array}$ & 3,66 \\
3 & $\begin{array}{l}\text { Hendaknya membantu petani memperbanyak pemakaian } \\
\text { pestisidahayati untuk meningkatkan kehidupan mikroba tanah }\end{array}$ & 4,30 \\
4 & $\begin{array}{l}\text { Hendaknya membantu petani mengurangi pemakaian pestisida } \\
\text { kimia untuk menurunkan risiko keracunan }\end{array}$ & 4,24 \\
& Rata rata & 4,08 \\
\hline
\end{tabular}

\section{PERILAKU KONSUMSI BERAS ORGANIK}

Proses pengambilan keputusan konsumen akan menghasilkan dua macam aktivitas pasca keputusan, yaitu perilaku pembelian dan evaluasi pasca pembelian. Konsumen membuat tiga macam pembelian, yaitu pembelian coba-coba (trial), pembelian berulang, dan pembelian komitmen jangka panjang. Pembelian cobacoba ditandai dengan jumlah yang lebih sedikit dari kebutuhan sesungguhnya, dilakukan pada saat pertama kali melakukan pembelian suatu produk yang digunakan oleh konsumen untuk menilai produk tersebut. Jika konsumen merasa puas terhadap produk tersebut, maka konsumen akan melakukan pembelian ulang yang biasanya dilakukan dalam jumlah yang lebih besar.
TABEL 8. PERILAKU KONSUMSI DAN MINAT KONSUMEN BERAS ORGANIK

\begin{tabular}{|c|c|c|c|}
\hline No & Uraian & $\begin{array}{l}\text { Jumlah } \\
\text { (Jiwa) }\end{array}$ & $\begin{array}{l}\text { Persentase } \\
(\%)\end{array}$ \\
\hline \multirow[t]{5}{*}{1} & Jumlah pembelian sebulan & & \\
\hline & $5-10 \mathrm{~kg}$ & 39 & 33 \\
\hline & $11-15 \mathrm{~kg}$ & 50 & 42 \\
\hline & $16-20 \mathrm{~kg}$ & 25 & 21 \\
\hline & lebih dari $20 \mathrm{~kg}$ & 5 & 4 \\
\hline \multirow[t]{5}{*}{2} & Proporsi konsumsi beras organik & & \\
\hline & Semua beras organik & 46 & 39 \\
\hline & Lebih banyak beras organik & 31 & 26 \\
\hline & Separoh konsumsi adalah beras organik & 29 & 24 \\
\hline & Lebih sedikit beras organik & 13 & 11 \\
\hline \multirow[t]{3}{*}{3} & Preferensi konsumen terhadap beras organik & & \\
\hline & Sama atau kurang suka & 32 & 27 \\
\hline & Lebih suka beras organik & 87 & 73 \\
\hline
\end{tabular}

Mayoritas konsumen mengkonsumsi beras organik sebanyak antara 5-15 kg (Tabel 8). Dilihat dari proporsi konsumsi beras organik dapat dikatakan bahwa lebih dari $60 \%$ konsumen masih membeli beras organik dan nonorganik untuk memenuhi kebutuhannya. Namun demikian, dapat dikatakan bahwa konsumsi beras organik lebih banyak dibandingkan dengan beras nonorganik.

Preferensi konsumen terhadap pangan secara umum dipengaruhi oleh faktor sosial demografis dan faktor psikologis. Secara khusus preferensi konsumen terhadap pangan organik dipengaruhi oleh kepedulian terhadap gizi keluarga (Rimal, 2002), faktor kepercayaan bahwa produk yang dikonsumsinya diproduksi secara organik (Shepherd etal, 2005), dan juga kepedulian terhadap kesehatan lingkungan. Hasil analisis preferensi konsumen disajikan dalam Tabel 9 berikut.

Hasil analisis diperoleh nilai Chi kuadrat model sebesar 78,995. Analisis ini menunjukkan bahwa variabel yang dipergunakan dalam model preferensi secara signifikan berpengaruh nyata terhadap variasi preferensi konsumen. Semua variabel mempunyai nilai koefisien regresi yang bertanda positif. Hal ini menunjukkan bahwa peningkatan nilai variabel akan menyebabkan peningkatan preferensi konsumen terhadap beras organik. Hasil analisis menunjukkan nilai R2 sebesar 0,482 yang menyatakan bahwa variabel yang digunakan sebagai penduga dalam penelitian ini mampu 
menjelaskan variasi variabel bebas sebesar 48,2\%. Hasil analisis menunjukkan juga bahwa variabel kepedulian terhadap keluarga mempunyai nilai koefisien regresi tertinggi, yaitu 2,684. Nilai koefisien regresi ini menunjukkan bahwa peningkatan skor kepedulian terhadap keluarga sebesar 1 satuan akan meningkatkan nilai odds preferensi konsumen sebesar 14,651 kali.

\section{KESIMPULAN}

Mayoritas konsumen beras organik berasal dari keluarga berpendapatan tetap, berpendidikan cukup tinggi, dengan ukuran keluarga yang kecil. Konsumen memberikan penilaian terhadap kualitas tampilan dan kualitas hasil tanakan beras organik dalam katagori sedang. Dengan demikian, beras organik tidak termasuk dalam katagori beras kualitas premium. Konsumen beras organik mempunyai kepedulian yang tinggi terhadap keluarga, persepsi terhadap tingkat kemurnian yang tinggi, dan kepedulian terhadap kesehatan lingkungan pertanian yang tinggi. Namun, konsumen masih mempunyai persepsi terhadap praktek pertanian organik yang dalam katagori sedang.

Hasil pertanian organik masih dipersepsikan sebagai produk yang mempunyai harga yang mahal. Namun, mayoritas konsumen lebih suka beras organik dari pada beras anorganik. Preferensi konsumen terhadap beras organik akan meningkat apabila terjadi peningkatan kepedulian konsumen terhadap keluarga, persepsi terhadap tingkat kemurnian, kepedulian terhadap kesehatan lingkungan pertanian, dan persepsi terhadap praktek pertanian organik

Untuk memperluas pasar beras organik diperlukan upaya untuk meningkatkan kepedulian konsumen terhadap berbagai dampak positif yang ditimbulkan dari praktek pertanian organik. Untuk itu maka diperlukan upaya untuk lebih menyebar luaskan informasi tentang kemanfaatan pertanian organik secara terpadu dalam pemasaran beras organik.

\section{DAFTAR PUSTAKA}

Badan Standardisasi Nasional. 2015. SNI 6729-2010 Sistem Pangan Organik (Online). Diakses 9 Februari 2015. www.bsn.go.id

Biao, X., Xiaorong, W., Zhuhong, D., \& Yaping, Y. 2003. Critical impact assessment of organic agriculture. Journal of Agricultural and Environmental Ethics 16: 297-311.

Canavari, M., Gazzani, G. M., Spadoni, R, \& Regazzi, D. 2002. Food safety and organic fruit demand in Italy: a survey. British Food Journal 104 (3-5): 220-232.

Connor, R., \& Douglas, L. 2002. Consumer attitudes to organic foods. Nutrition and Food Science 31 (4/5): 254-258.

Engel, J. F., Blackwell, R. D., \& Miniard, P. W. 1993. Perilaku Konsumen: Edisi 6. Binarupa Aksara, Jakarta.

Fotopoulos, Christos, \& Krystallis, A. 2002. Purchasing motives and profile the Greek organic consumer: a countrywide survey. British Food Journal 104 (8/9): 730-765.

Gianluigi, G., Prete, M. I., Peluso, A. M., R. Maloumby-Baka, C., \& Buffa, C. 2009. The role of ethics and product personality in intention to purchase organic food products: a structural equation modeling approach. Int Rev Econ.

IFOAM, 2009. The 2009 Annual Report (Online). Diakses 17 Februari 2010. www.ifoam.org.

Malhotra, N. M. 2004. Marketing Research: An Applied Orientation, Fourth Edition. Prentice Hall, Saddle River, NJ.

Peter, \& Olson. 1996. Consumer Behavior. McGraw Hill co.

Ricciuto, L., Tarasuk, V., \& Yatchew, A. 2006. Socio-demographic influence on food purchasing among Canadian koueholds. European Journal of Clinical Science 60: 778-790.

Rimal, A. P. 2002. Factors affecting meat preferences among American consumers. Family Economics and Nutrition Review 14 (2): 36-43.

Schiffman, L. G., \& Kanuk, L. L. 1997. Consumer Behavior: 6th Edition. Prentice Hall International, Inc.

Shepherd, Richard, Magnusson, M., \& Sjoden, P. 2005. Determinant of consumer behaviour related to organic foods. Ambio 34 (4/5): 352-359.

Sangkumchaliang, Parichard, \& Huang, W. C. 2012. Consumers' perceptions and attitudes of organic food products in Northern Thailand. International Foods and Agribusiness Management Review 15: 87-102.

Unnevehr, L. J., Duff, B., \& Juliano, B. O.1992. Consumer demand for rice grain quality: introduction and major finding. Dalam Consumer Demand for Rice Grain Quality. IRRI, Manila.

TABEL 9. ANALISIS PREFERENSI KONSUMEN TERHADAP BERAS ORGANIK

\begin{tabular}{lllll}
\hline Variabel & $\begin{array}{l}\text { Koefisien } \\
\text { regresi }\end{array}$ & Nilai - $\mathbf{z}$ & Signifikansi & Eksponensial \\
\hline Persepsi mutu beras organik & 2,248 & 5,349 &, 021 & 9,471 \\
$\begin{array}{l}\text { Kepedulian terhadap kesehatan } \\
\text { lingkungan hidup }\end{array}$ & 1,961 & 6,168 &, 013 & 7,105 \\
Kesadaran pada makanan keluarga & 2,684 & 8,061 &, 005 & 14,651 \\
Persepsi pada produk organik & 2,072 & 3,538 &, 060 & 7,941 \\
Constant & $-35,584$ & 25,948 &, 000 &, 000 \\
& Chi kuadrat $=78,995$ & Cox \& Snell $R^{2}=0,482$ \\
\hline
\end{tabular}


142

Jurnal AGRARIS

Zander, Katrin, \& Hamm, U. 2010. Consumer preference for additional ethical attributes of organic food. Food Quality and Preference 21: $495-503$. 